\title{
Is the Worst Over? Economic Indexes and the Course of the Recession in New York and New Jersey
}

\author{
Jason Bram, James Orr, Robert Rich, Rae Rosen, \\ and Joseph Song
}

The New York-New Jersey region entered a pronounced downturn in 2008, but the pace of decline eased considerably in spring 2009 and then leveled off in July, according to three key Federal Reserve Bank of New York economic indexes. These developments, in conjunction with a growing consensus that the national economy is headed for recovery, suggest that the worst may be over for the region's economy. However, a downsizing of the area's critical finance sector could pose a major risk to the economic outlook going forward - particularly for New York City.

A ccording to the National Bureau of Economic Research (NBER), the U.S. economy entered a recession in December 2007. While this determination is of considerable importance, the decision was not announced until November 28, 2008almost a year after the onset of the episode. Such lags in the dating of business-cycle turning points have prompted interest in producing real-time indicators of the U.S. economy's performance. In the late 1960s, the Department of Commerce developed a methodology that combines several data series into a coincident index - a single composite measure intended to gauge the current state of the aggregate economy. Today, this national coincident index provides a broad and timely measure of U.S. economic activity each month. ${ }^{1}$

If national and regional business cycles were synchronized, a national coincident index would be sufficient to track fluctuations in regional economic activity. However, evidence from a number of studies indicates marked differences between regional and U.S. cycles. ${ }^{2}$ As a result, analysts who must monitor regional business conditions are best advised to focus on measures that reflect economic activity at the local level. To assist in this effort, economists at the Federal Reserve Bank of New York have constructed indexes of coincident economic indicators (CEIs) for New York State, New York City, and New Jersey. ${ }^{3}$ The regional CEIs draw upon information from four key data series: nonfarm payroll employment, real earnings (wages and salaries), the unemployment

\footnotetext{
${ }^{1}$ Although peaks and troughs in the national coincident index tend to coincide with the dating of business cycles by the NBER, the Bureau determines recession dates judgmentally after considering many factors. The national coincident index is now produced by the Conference Board.

${ }^{2}$ For example, see Orr, Rich, and Rosen (1999), Crone (2004), Wall and Zoega (2004), and Crone and Clayton-Matthews (2005).

${ }^{3}$ See Orr, Rich, and Rosen (1999).
} 
rate, and average weekly hours worked in the manufacturing sector. ${ }^{4}$ The indexes enable us to analyze the region's current recession and to date historical business cycles specific to New York State, New York City, and New Jersey since the mid-1960s. In addition, they provide a basis for comparing cycles in the New York-New Jersey region with each other and with national cycles. ${ }^{5}$

In this issue of Second District Highlights, we use our three CEIs to provide an update on economic activity in the New York-New Jersey region as of July 2009. As part of our assessment, we present a brief description of the formal statistical model used to estimate the regional CEIs (see the appendix). We also offer insight into the dynamics of the current cycle by looking at some of the individual component indicators of each CEI. Our CEIs show that the region entered a pronounced downturn in 2008, a number of months after the onset of the national recession in December 2007. This lag suggests that the regional economy had more momentum and showed more resilience than the national economy during the early stages of the current national recession. The delay in the start of the region's downturn relative to the nation's contrasts sharply with the sequence of events at the time of the 1990-91 and 2001 U.S. recessions, when the regional downturn preceded the national recession-in the first case, by more than a year. The current recession hit the region with full force in fall 2008, with significant job losses occurring across most industry sectors and geographic areas.

During spring 2009, however, the pace of decline moderated considerably, and in July the indexes leveled off. This, in conjunction with a growing consensus that the national economy is poised for recovery, is a hopeful sign and greatly increases the likelihood that the worst is over for the region's economy. Still, it should be cautioned that seismic changes to the critical finance sector pose a major risk to the economic outlook for the region-particularly for New York City, which has already experienced a steeper downturn than a number of metropolitan areas in upstate New York. With these risks in mind, we close by discussing factors likely to shape the timing and extent of a recovery in the region.

\section{Current Economic Activity in the Region}

Our CEIs afford a comprehensive view of historical and current economic activity in New York State, New York City, and New Jersey (Charts 1-3). The top panels of each chart depict the historical behavior of the index starting in the mid-1960s, while the bottom panels focus on the last fourteen years. The bottom panels allow us to examine more closely the recent behavior of the CEI, while the top panels allow us to compare it with previous downturns. We also include vertical bands indicating the peak-to-trough periods for each

\footnotetext{
${ }^{4}$ The emphasis on labor market indicators reflects limited data availability. Relatively few economic time series available at the state and local level meet our criteria of reliability, timeliness, and historical continuity. The choice of the four data series parallels that of the Federal Reserve Bank of Philadelphia in its construction of CEIs for New Jersey, Pennsylvania, and Delaware. See $<$ http:// www.phil.frb.org/research-and-data/regional-economy/indexes/coincident/>.

${ }^{5}$ The indexes have also been found to be useful in projecting state and local tax revenues; see Rich et al. (2005).
}

national business cycle as defined by the NBER and shade the peakto-trough period of each local downturn as defined by our CEI. ${ }^{6}$

The indexes show that the New York-New Jersey region has experienced a severe economic downturn. All CEIs peaked during 2008 and were down substantially from their peaks as of July 2009. Although the two state CEIs peaked noticeably earlier than the CEI for New York City, all three peaks occurred after the cyclical peak in national economic activity in December 2007. ${ }^{7}$

In New York State, the peak in economic activity was reached in February 2008, and the index contracted at a 5.7 percent annual rate through June 2009 before turning up modestly in July (Chart 1). Most of the deterioration in the state economy, however, occurred after October 2008, when the pace of decline accelerated noticeably. The current level of activity is now below the peak reached in the previous cycle in 2000.

In New York City, the upward momentum in economic activity in the current cycle was maintained through June 2008, although the deterioration has been rapid since then (Chart 2). In the twelve months ending in June 2009, activity decreased by 4.9 percent, then flattened out in July. The level of activity, however, currently remains well above the prior cyclical peak in 2000 as a result of the city's robust economic growth during the last expansion.

In New Jersey, as in New York State, the peak of activity was reached in February 2008, just two months after the start of the national recession (Chart 3). An examination of the state's CEI leading up to the peak, however, reveals a prolonged period of relatively weak growth that began in early 2007 as New Jersey's economic expansion began to lose steam. For much of 2007 into early 2008, the index showed that growth was only modestly positive; it also displayed outright declines each month between July and October 2007. After peaking in February 2008, activity declined at a 5.0 percent annual rate through mid-2009 but leveled off in July. The index now stands below the trough of the previous downturn.

In both New York State and New Jersey, the lag in the onset of the current downturn relative to that of the nation differs markedly from the two prior episodes, in which the peak of activity in both states occurred before the national peak. In particular, in the late 1980s the downturns in New York State and New Jersey began about eighteen months before the start of the 1990-91 national

\footnotetext{
${ }^{6}$ Our method of dating peaks and troughs of local business cycles differs from the method used by the NBER to date national cycles. The NBER examines a variety of economic time series to make a judgment about when a national cycle has begun or ended. By contrast, our criteria for dating regional business cycles rely on an inspection of the peaks and troughs of the estimated regional CEIs. This approach is again a consequence of the limited data availability at the state and local levels. The CEIs, however, are generally quite smooth, and the identification of regional peaks and troughs is fairly straightforward. Yet on a few occasions, such as the dating of the most recent peak for New Jersey, the turning point was based on a more judgmental determination.

${ }^{7}$ The specific months that currently identify regional peaks and troughs could change as a result of subsequent data revisions. In the past, these changes have been minor, usually in the range of one to two months.
} 

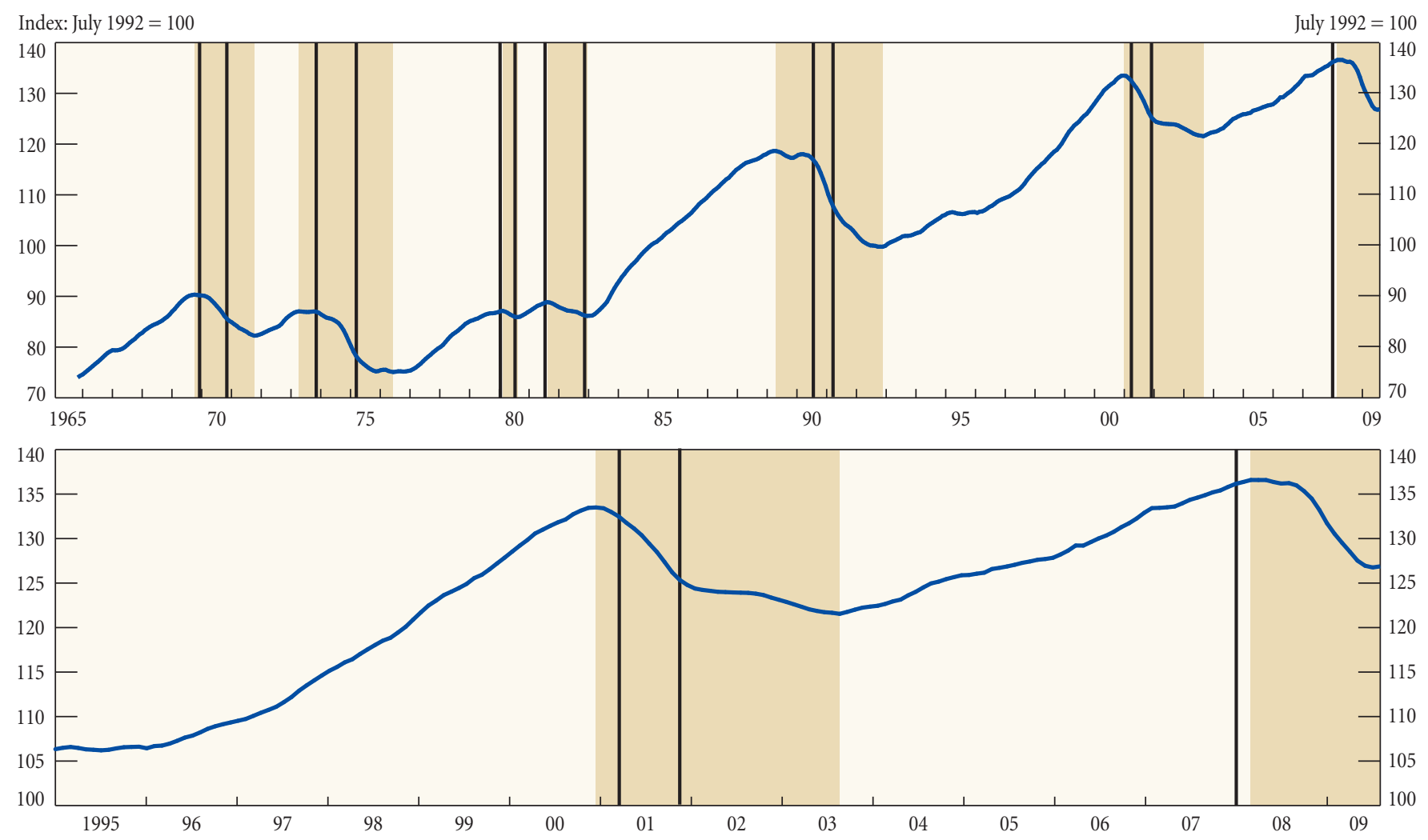

Source: Federal Reserve Bank of New York.

Note: The black vertical bands indicate the peak-to-trough periods of each national business cycle as defined by the National Bureau of Economic Research; the shaded areas indicate the peak-to-trough periods of New York State's downturns as defined by our index of coincident economic indicators.

downturn. ${ }^{8}$ As Charts 1-3 show, disparities in the timing of downturns in the region and the nation are seen more broadly over our full sample period, with only the 1980 and 1982 downturns in New York State and New Jersey roughly coinciding with the U.S. cycle. In New York City, cycles have generally shown even less correspondence with those of the nation.

In addition, disparities can be seen in the timing of troughs in the region and in the nation. Notably, the recoveries in New York State, New York City, and New Jersey tend to begin much later than the national recovery. Following both the 1989 and 2001 downturns, for example, regional activity failed to recover until well after the trough in national activity. In some episodes, the regional recovery did not take hold for more than a year after the end of the national recession.

These disparities in the timing and duration of business cycles in the New York-New Jersey region and the nation reflect

\footnotetext{
${ }^{8}$ At that time, the region's concentration in finance was an important reason for the weak activity in both states; the downturn in the financial sector occurred well before the national economy went into recession. See Bram, Orr, and Rosen (2008), McCarthy and Steindel (1997), and Kuttner and Sbordone (1997).
}

differences in industrial structures as well as the influence of local-specific factors, such as commercial and residential building cycles and fiscal conditions. Also, the cyclical dynamics of a mature economy - that is, one with a low population growth rate, high land prices, and a high density of activity, such as the New York-New Jersey region-are likely to differ from the dynamics of rapidly growing economies, such as the Southwestern states.

\section{Recent Developments in the New York-New Jersey Region}

\section{New York State}

The specific components of New York State's CEI reveal that much of the state's economic weakness stems from sharp job losses in the first half of 2009 and the related steep rise in the unemployment rate. Looking back, one can see that job growth in the state averaged less than 1.0 percent in both 2005 and 2006-a figure that was only about half the nationwide rate. In 2007, however, as U.S. job growth slowed, statewide growth picked up and surpassed the national pace. In the first half of 2008, as U.S. employment turned downward, New York State job growth slowed sharply but remained positive through June. It was not until October 2008 that the pace of job loss in the state gathered momentum. Similarly, the state's unemployment rate, 


\section{Economic Activity in New York City}
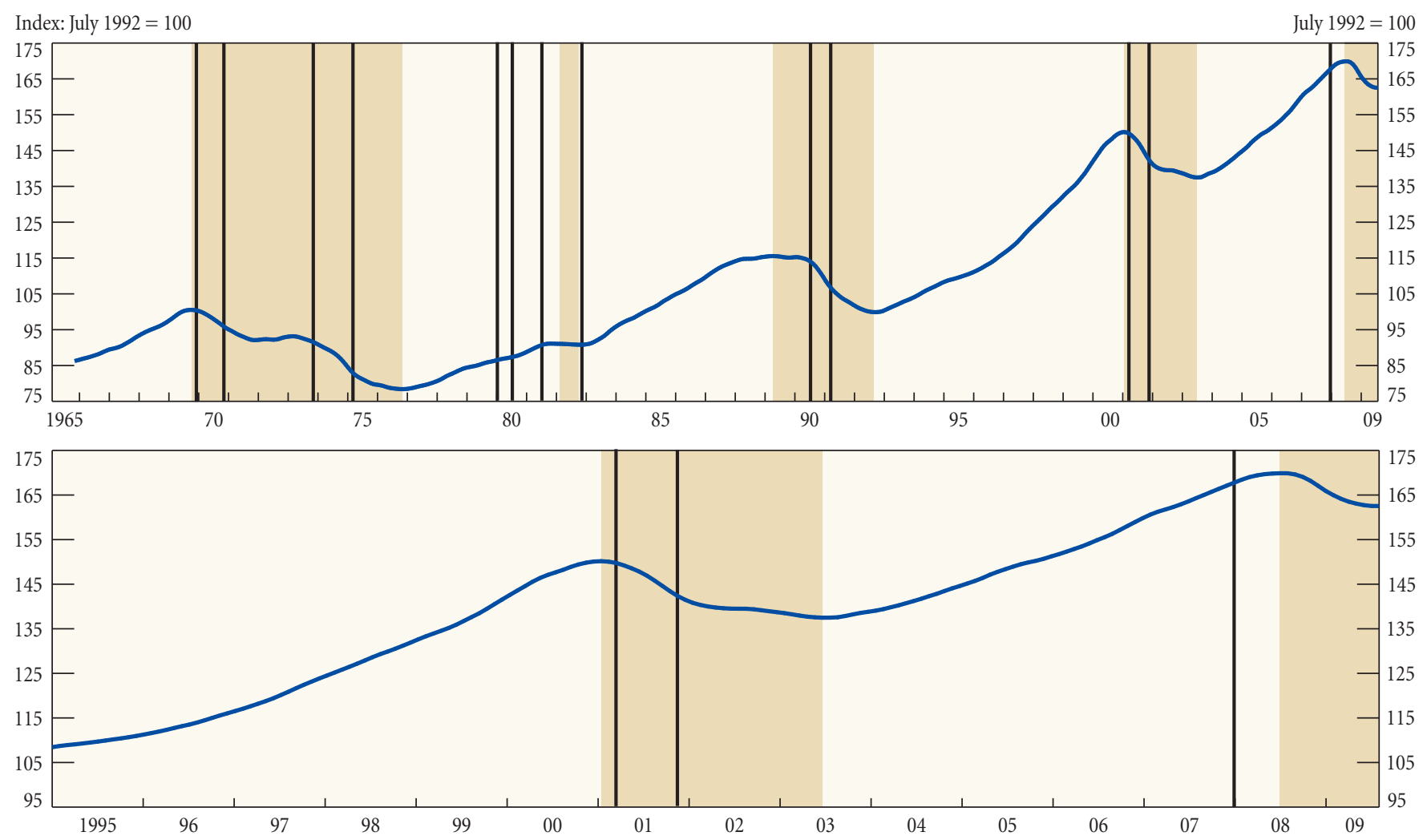

Source: Federal Reserve Bank of New York.

Note: The black vertical bands indicate the peak-to-trough periods of each national business cycle as defined by the National Bureau of Economic Research; the shaded areas indicate the peak-to-trough periods of New York City's downturns as defined by our index of coincident economic indicators.

which began to edge up in April 2008, rose only moderately through last October. By June 2009, however, it had surged 2.8 percentage points, to 8.7 percent, though it leveled off in July.

The steepest job loss rates have been in the construction and manufacturing sectors. Construction employment had been rising through August 2008, but fell sharply thereafter, whereas manufacturing employment simply registered a moderate acceleration in its secular downward trend. The financial sector has also contributed substantially to the decline in employment, particularly in New York City. However, statewide, more than half of the overall job losses have been in the professional and business services sector and the trade, transportation, and utilities sectors, which together account for 30 percent of state employment. Although the state's job losses have been fairly broad-based, the education and health services sector has continued to add jobs, offsetting some of the weakness in other sectors - a pattern similar to that observed in past downturns.

Geographically, it appears that somewhat more of the decline in economic activity statewide has occurred in New York City and its surrounding areas than in upstate. Even though we do not calculate indexes for any substate area other than New York City, we can gauge the relative performance of the various metro areas from local employment trends. From April 2008 to June 2009, statewide employment declined 2.6 percent. Over that period, jobs fell 2.9 percent in the New York City metro area (which includes Long Island and the Lower Hudson Valley), compared with declines of 1.7 percent or less in the Utica, Syracuse, and Rochester areas and 2.5 percent in metropolitan Albany. Job losses in the Buffalo and Binghamton areas were close to those in Albany. Parts of the District did see an upturn in employment in July 2009, largely reflecting public sector summer jobs programs.

This divergence in job growth between upstate New York and the New York City metro area contrasts with their relative performance during the last expansion. Over that period, upstate lagged the city in job growth by a wide margin. Going forward, it will be of considerable interest to learn whether the more recent pattern of geographical differences in job trends persists.

\section{New York City}

Although national employment levels began to decline in December 2007, jobs in New York City continued to grow at a moderate clip into 2008, peaking in August of that year. In the city, broad-based 

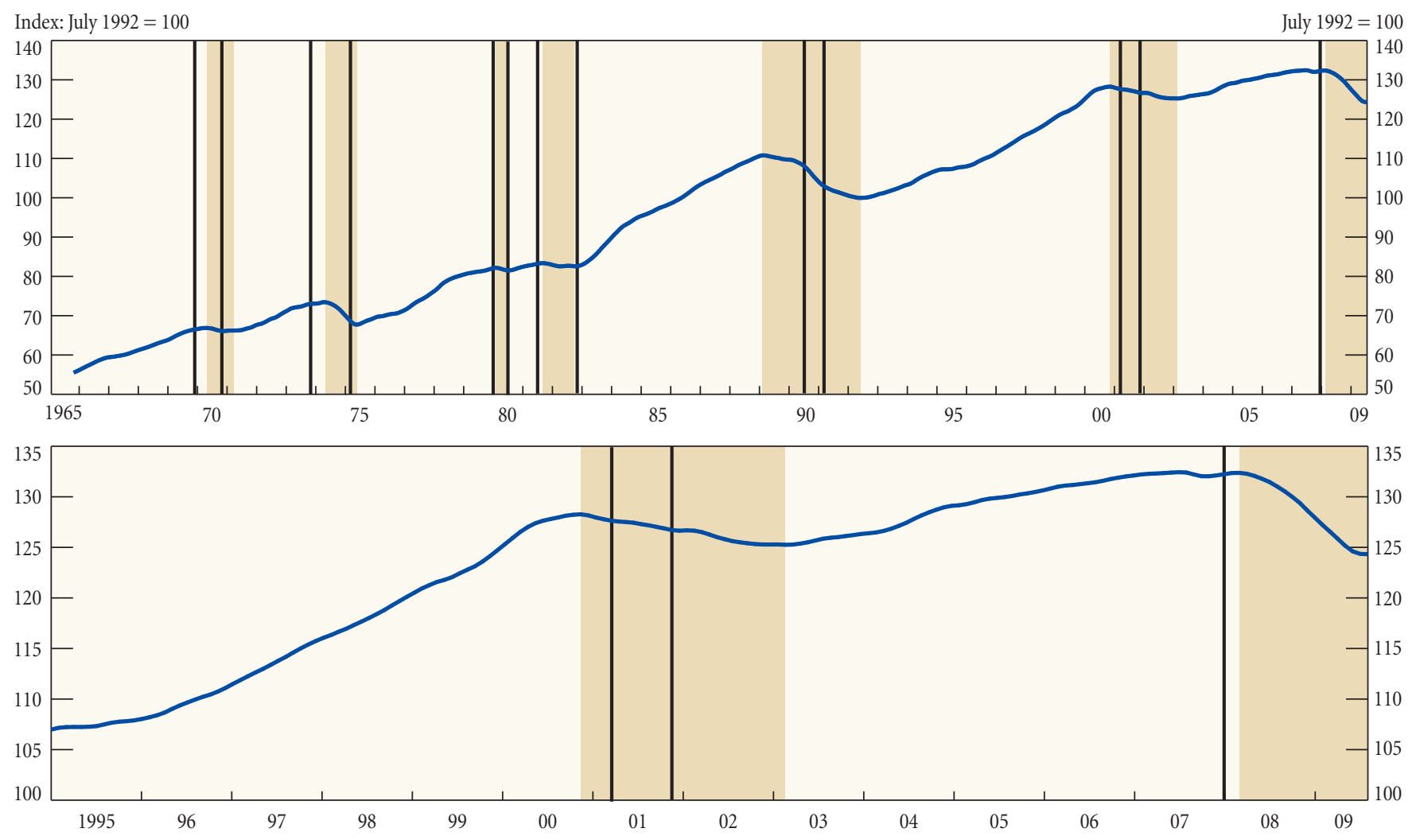

Source: Federal Reserve Bank of New York.

Note: The black vertical bands indicate the peak-to-trough periods of each national business cycle as defined by the National Bureau of Economic Research; the shaded areas indicate the peak-to-trough periods of New Jersey's downturns as defined by our index of coincident economic indicators.

growth in large sectors, such as health and education services and business and professional services, more than offset the employment declines that were developing in the financial services sector and were ongoing in the manufacturing sector. Employment in the city was also buoyed late into the cycle by growth in the leisure and hospitality sector, as the weakened dollar helped make the United States - and particularly the country's New York City "gateway" an attractive tourist destination.

The recent weakness in the financial services sector is the key factor underlying the city's current downturn. Financial services represent about 12 percent of employment in the city, although the historically high base wages and bonus payments in that sector account for a significantly larger share of income - as much as 30 percent of total wages in a peak year. Largely because of these exceptionally high wages, each job in the city's securities industry- "Wall Street" - is estimated to generate two additional jobs in the city. ${ }^{9}$ These jobs can be in services that support the industry, such as advertising, accounting, and legal services, or in services that benefit from the relatively high income of these workers,

\footnotetext{
${ }^{9}$ The employment multiplier was obtained from the U.S. Bureau of Economic Analysis' RIMS II model (<https://www.bea.gov/regional/rims $>$ ).
}

such as restaurants and real estate. In addition, the relatively large contribution of the securities industry to the city's income makes the industry an important source of tax revenue, directly through income taxes and indirectly through sales and property taxes. Thus, job losses in the city's securities industry have a disproportionate impact on the region's total activity.

The headline news stories of New York City's financial sector layoffs in the tens of thousands started as early as fall 2007, but these numbers were slow to be reflected in the local employment counts. ${ }^{10}$ Job declines in that sector began to appear in early 2008 , however, and financial sector employment in the city as of July 2009 was down roughly 42,000 from its January 2008 peak, with no letup in the pace of decline.

\footnotetext{
${ }^{10}$ Some reported losses may not have appeared in the actual job declines in New York City for several reasons. First, firms headquartered in the city tended to announce firmwide layoffs without regard to location. Affected employees could be anywhere in the United States, or even abroad. Second, the layoffs were frequently an outgrowth of firm restructuring and included many highly compensated individuals. It is not unusual for termination packages for such professionals to include six months' to as much as a year's severance pay and outplacement services. Depending upon an individual's contract, such job losses might not be counted in official employment reports until the severance package and/or outplacement service had ended.
} 
New Jersey

Weakness in employment has contributed significantly to the recent sluggishness in New Jersey's CEI. Total employment in the state peaked in January 2008, but as of June 2009 it had fallen by a little more than 160,000 - a decline of 3.9 percent. As in New York State, however, employment rose modestly in July. Job losses have been concentrated in the private sector and have influenced most of the state's key industries over the past year. National job trends negatively affecting several industries have been mirrored in state employment declines. Most striking has been the weakness in the finance sector. Because of the relative concentration of banks and other financial firms in the state linked to home mortgage financing, the negative effect of the unfolding financial market turmoil was seen early on in the sector. Moreover, New Jersey's financial sector has been subject to adverse conditions similar to those affecting New York City's. Employment in the financial activities sector peaked in September 2005, but is now down 9.1 percent, or slightly more than 25,000 jobs. In conjunction with the fallout from the financial crisis, employment in both real estate services and residential construction in the state has shrunk.

After experiencing only mild losses through July 2008, New Jersey's professional and business services sector saw employment begin to decline, and by June 2009 the sector had shed more than 42,000 positions. Employment has dipped in the leisure and hospitality industry, which has seen losses in casino hotel employment. Trade and transportation employment has been pulled down by heavy losses in the trucking industry.

New Jersey has also experienced relatively significant job losses in manufacturing. Employment in this sector has been undergoing a long-term deterioration, but the rate of manufacturing job losses picked up in the second half of 2008. Over the past year, government employment levels have been down only modestly. The only substantive source of growth in the state continues to be the education and health sector. Jobs there expanded throughout the previous downturn and are currently growing at a year-overyear pace of 1.0 percent. Colleges and professional schools were an important source of job gains in education, and the ambulatory care and social assistance industries were the key source of gains in health services.

Reflecting the generally adverse job trends in the state, as well as job losses among commuters to New York City, New Jersey's unemployment rate has risen sharply. The July 2009 rate of 9.3 percent was up 4.0 percentage points from a year earlier. This monthly reading was the highest since 1977, when the state was emerging from a prolonged downturn.

\section{Outlook for the Region}

The recent leveling off in all three CEI indexes is a promising sign that the worst of the region's economic troubles may be over. So, too, is recent evidence that the national economy may be turning around-seen, for example, in the July forecast from Blue Chip Economic Indicators, which predicts positive U.S. growth starting in the third quarter of the year. Such a rebound in national activity would clearly spur the New York-New Jersey region's own recovery. Nevertheless, considerable uncertainty attends most forecasts of a business-cycle turning point, and the current cycle is no exception. In particular, both the timing and strength of the region's recovery will likely depend on the success of efforts to restore smoothly functioning financial markets.

Although the New York-New Jersey economy shows tentative signs of stabilization, a number of factors make it likely that the region's recovery will lag the nation's, just as it has in the past. First, this economic cycle is characterized by unusual restructuring in the financial sector. Ongoing consolidations, mergers, and financial firm closures suggest that employment in the sector may not return to its previous cyclical highs. Additionally, future regulatory changes could limit the permissible lines of business, pay structure, and size of firms. The form, shape, and timing of these forces are unknown, but they certainly have the potential to dramatically reshape this sector and play an important role in the region's recovery-particularly New York City's.

Second, state and local fiscal pressures could delay the regional recovery. As we observed earlier, the financial sector can account for as much as 30 percent of all earnings in New York City. The job and income losses in this sector and in related supporting services, as well as the more broad-based cyclical job losses attributable to the national recession, have already led to a sizable plunge in state and local income and sales tax collections. Such declines are likely to continue and to be exacerbated by steep reductions in mortgage-related tax revenues, reflecting the drop in home sales, and decreases in capital gains and corporate tax collections, reflecting a weaker economy and stock market. ${ }^{11}$ These decreases in tax revenue have helped create a bigger budget gap, which states and cities typically seek to remedy through a combination of tax increases and spending cuts-measures that can crimp regional economic activity.

Third, employment growth in the private education and health sector has historically contributed some stability to state and local economies, because the demand for these services is not closely linked to cycles in the regional economy. However, the current downturn is characterized by such severe gaps between projected tax revenue collections and projected expenditures that state and municipal governments are instituting cuts in aid to these sectors. Thus, continuing job gains in health care, although possible, now appear more questionable. Finally, even if the national economy were to rebound in the second half of 2009, many analysts anticipate that a recovery in U.S. employment will trail the general economic recovery. All of these factors, coupled with the New York-New Jersey region's historical tendency to lag the nation when emerging from a recession, point to a period of sluggish activity for the region even as the U.S. economy begins to recover.

\footnotetext{
11 The possibility of tax-loss carry-forwards for financial corporations makes a drop in corporate tax collections all the more likely.
} 


\section{APPENDIX}

\section{Construction of the Federal Reserve Bank of New York's Regional Coincident Economic Indexes}

To construct the coincident indexes for New York State, New York City, and New Jersey, we apply the Stock-Watson (1989) methodology to four data series: nonfarm payroll employment, real earnings (wages and salaries), the unemployment rate, and average weekly hours worked in manufacturing. A key assumption of the statistical framework is that a single (unobserved) factor drives the comovements in the various measures of regional economic activity. This common component forms the basis for the coincident index that measures "the state of the economy." In addition to the common component, movements in the measures of regional economic activity reflect the influence of idiosyncratic factors. Formally, the unobserved single-index (or dynamic-factor) model can be written as

$$
\begin{aligned}
& \Delta X_{t}^{1}=\lambda_{0}^{1} \Delta C_{t}+\lambda_{1}^{1} \Delta C_{t-1}+\ldots \lambda_{j}^{1} \Delta C_{t-j}+\varepsilon_{t}^{1} \\
& \vdots \\
& \Delta X_{t}^{i}=\lambda_{0}^{i} \Delta C_{t}+\lambda_{1}^{i} \Delta C_{t-1}+\ldots \lambda_{j}^{i} \Delta C_{t-j}+\varepsilon_{t}^{i},
\end{aligned}
$$

where $\Delta X_{t}^{i}$ denotes the change in the $i$ th coincident variable at time $t$, $\Delta C_{t}$ denotes the change in the common factor at time $t, \varepsilon_{t}^{i}$ denotes the idiosyncratic shock to the $i$ th coincident variable at time $t$, and $\lambda_{j}^{i}$ is the parameter (factor loading) on the $j$ th lagged value of the change in the common factor for the $i$ th coincident variable. Stock and Watson discuss

\section{References}

Blue Chip Economic Indicators. 2009. Vol. 34, no. 7 (July).

Bram, Jason, James Orr, and Rae Rosen. 2008. "Employment in the New YorkNew Jersey Region: 2008 Review and Outlook.” Federal Reserve Bank of New York Current Issues in Economics and Finance 14, no. 7 (September-October).

Crone, Theodore M. 2004. "A Redefinition of Economic Regions in the U.S." Federal Reserve Bank of Philadelphia Working Paper no. 04-12, September.

Crone, Theodore M., and Alan Clayton-Matthews. 2005. “Consistent Economic Indexes for the 50 States." Review of Economics and Statistics 87, no. 4

(November): 593-603.

Kuttner, Kenneth N., and Argia M. Sbordone. 1997. "Sources of New York Employment Fluctuations.” Federal Reserve Bank of New York Economic Policy Review 3, no. 1 (February): 21-35.

McCarthy, Jonathan, and Charles Steindel. 1997. "National and Regional Factors in the New York Metropolitan Economy." Federal Reserve Bank of New York Economic Policy Review 3, no. 1 (February): 5-19. additional assumptions of the model and describe how the model can be estimated by maximum likelihood using the Kalman filter, with the coincident index being the estimated value of the common factor, $\hat{C}_{t}$.

Alternatively, the coincident index can be expressed as a weighted average of the coincident variables:

$$
\Delta C_{t}=\sum_{k=0} w_{k}^{1} \Delta X_{t-k}^{1}+\ldots+\sum_{k=0} w_{k}^{i} \Delta X_{t-k}^{i},
$$

where $w_{k}^{i}$ is the weight on the $k$ th lagged value of the change in the $i$ th coincident variable. The weights associated with the CEIs are determined through model estimation. A more detailed description of the data and the estimation procedures used to construct the CEIs can be found at $<$ http://www.newyorkfed.org/research/regional_economy/ construction_frbny_cei.pdf $>$.

The regional CEIs have been in production at the Federal Reserve Bank of New York since 1999. The indexes are updated monthly and can be found at <http://www.newyorkfed.org/research/regional_economy/ coincident_summary.html $>$.

Orr, James, Robert Rich, and Rae Rosen.1999. “Two New Indexes Offer a Broad View of Economic Activity in the New York-New Jersey Region." Federal Reserve Bank of New York Current Issues in Economics and Finance 5, no. 14 (October).

Rich, Robert, Jason Bram, Andrew Haughwout, James Orr, Rae Rosen, and Rebecca Sela. 2005. "Using Regional Economic Indexes to Forecast Tax Bases: Evidence from New York." Review of Economics and Statistics 87, no. 4 (November): 627-34.

Stock, James H., and Mark Watson. 1989. "New Indexes of Coincident and Leading Economic Indicators." In Olivier Jean Blanchard and Stanley Fischer, eds., NBER Macroeconomics Annual 1989, 351-94. Cambridge, Mass.: MIT Press.

Wall, Howard J., and Gylfi Zoega. 2004. "U.S. Regional Business Cycles and the Natural Rate of Unemployment." Federal Reserve Bank of St. Louis Review 86, no. 1 (January-February): 23-31.

The authors thank Alan Clayton-Matthews for the computer program used to construct the regional indexes based on the Stock-Watson methodology.

\section{ABOUT THE AUTHORS}

Jason Bram is a senior economist and James Orr an assistant vice president in the Microeconomic and Regional Studies Function of the Research and Statistics Group; Robert Rich is an assistant vice president in the Macroeconomic and Monetary Studies Function of the Group; Rae Rosen is a senior economist and assistant vice president in the Bank's Regional Affairs Office; Joseph Song is an assistant economist in the Microeconomic and Regional Studies Function.

Current Issues in Economics and Finance is published by the Research and Statistics Group of the Federal Reserve Bank of New York. Linda Goldberg and Charles Steindel are the editors.

Subscriptions to Current Issues are free. Write to the Media Relations and Public Affairs Department, Federal Reserve Bank of New York, 33 Liberty Street, New York, N.Y. 10045-0001, or send an e-mail to pipubs@ny.frb.org.

The views expressed in this article are those of the authors and do not necessarily reflect the position of the Federal Reserve Bank of New York or the Federal Reserve System. 